\title{
Timo Slootweg, Uit de schaduw van de wet. Inleiding tot de esthetica van het recht (Antwerpen/Apeldoorn: Garant, 2016), 340 p.
}

\author{
Harry Groenenboom
}

De hoofdvraag van dit boek is of het mogelijk is om met wat Slootweg noemt 'postmoderne existentiefilosofie' toegang tot het recht te krijgen. De inzichten die Slootweg wil delen, zijn wat ongrijpbaar en bewust subjectief. Een praktisch gevolg daarvan voor deze recensie is, dat een samenvattende beschrijving van de inhoud van het boek aan de hand van de verschillende hoofdstukken daarvan, geen vruchtbare onderneming is. Hierna volgt dan ook een, noodzakelijkerwijs subjectieve, interpretatie waarbij getracht wordt de belangrijkste ideeën van het boek recht te doen.

De titel van het boek bevat een verwijzing naar het Bijbelse verhaal van de zondeval in Genesis 3. De schaduw waar de titel van spreekt, slaat op de schaduw van de boom van kennis van goed en kwaad, die in het paradijs stond. Slootweg is gegrepen door de 'merkwaardige kennistheoretische implicaties' die het verhaal van de zondeval heeft. Hij begrijpt het verhaal zo, dat wij als het ware in de schaduw van de boom van kennis van goed en kwaad, waarin Slootweg een metafoor ziet voor de wet, naar rechtvaardigheid en recht zoeken. Hij werkt deze gedachte in het boek zo uit, dat als gevolg van de zondeval de mens met zijn rede onderscheid is gaan maken tussen goed en kwaad. Met een instemmende verwijzing naar de Duitse theoloog Karl Barth stelt Slootweg dat de mens door de zondeval ethicus werd. Daaruit komt dan onvrijheid en onmenselijkheid voort, ook in het recht.

Slootweg wil verder laten zien dat wij buiten de zuivere rede, in wat Slootweg noemt het 'Bijbels personalisme', de meest geschikte en werkelijkheidsgetrouwe aanknopingspunten vinden ter exploratie en waardering van het esthetische of kunstzinnige gehalte van moraal en recht. In plaats van over bijbels existentialisme spreekt Slootweg ook vaak over 'existentialistisch personalisme' of 'christelijk existentialisme'. Deze begrippen worden nergens gedefinieerd en lijken onderling inwisselbaar te zijn.

Maar het boek gaat niet alleen over ethiek, recht en religie. Het wil ook inleiden tot de esthetica van het recht. In dat verband stelt Slootweg dat filosofie zich ten opzichte van de vakwetenschappen, die historisch gezien uit de filosofie zijn voortgekomen, moet onderscheiden als 'de vrije kunst van het kennen'. In de filosofie moet het niet gaan om waarheid en nut, maar om schoonheid en spel. Ook de rechtsgeleerdheid moet wat hem betreft, als erfgenaam van de filosofie, vrije kunst zijn. Zo kan er aandacht zijn voor het persoonlijke en unieke, iets wat Slootweg kenmerkend acht voor het postmoderne denken. Hij juicht dat zeer toe. Wat hij bepaalt niet toejuicht, maar als een groot kwaad aan de kaak stelt, is dat 
in zijn optiek de wetenschap, ook de rechtsgeleerdheid en rechtsfilosofie, uitsluitend gericht zijn op het begripsmatige en algemene. En daarmee dus, zo luidt zijn beschuldiging, onpersoonlijk geworden zijn. Slootweg stelt dan ook de vraag aan de orde of met postmoderne existentiefilosofie überhaupt toegang tot het recht kan worden verkregen. Kan het recht vanuit het leven begrepen worden, of moet het worden afgewezen als iets wat met het leven in eigenlijke zin niets van doen heeft? Slootweg ziet dus een tegenstelling tussen enerzijds de 'postmoderne existentiefilosofie' die wordt vereenzelvigd met 'het leven', en anderzijds 'het recht', waarvan betwijfeld wordt of dat met het leven verenigbaar is. Onder 'het leven' verstaat Slootweg dan 'persoonlijk' of 'authentiek' leven, ook wel aangeduid als 'existeren'. Wetenschap, rechtsgeleerdheid en rechtsfilosofie vervreemden juist daarvan, en dat is iets wat Slootweg te vuur en te zwaard bestrijdt.

Een en ander wordt gedramatiseerd in het beeld van een rechtszaak, dat Slootweg introduceert. De aangeklaagde partij is het rationalisme, dat volgens de auteur in het recht prominent aanwezig is, en van het recht een twijfelachtige bezigheid maakt. De rede en het rationalisme worden aangeklaagd voor hun 'wederrechtelijke onverschilligheid ten aanzien van het singuliere'. De aanklager wordt niet met zoveel woorden genoemd, maar kan niets anders zijn dan de postmoderne existentiefilosofie die Slootweg vertolkt.

Dat Slootweg zijn betoog als een rechtszaak presenteert, impliceert een subjectieve, partijdige en beschuldigende benadering van de aangeklaagde partij. Dat subjectieve element is wat Slootweg betreft zeker geen probleem. Alle ware filosofie vertrekt volgens hem steeds vanuit het subject. Objectiviteit acht hij onfilosofisch en onwetenschappelijk omdat die ons de weg tot de werkelijkheid, en vooral het zicht op de concrete mens, ontneemt. De ware beslissing is niet de keuze tussen een vooraf gegeven goed en kwaad, maar de keuze waardoor goed en kwaad worden gecreëerd. Ethiek moet daarom scheppend en creatief zijn, en leiden tot een esthetisch oordeel 'voorbij goed en kwaad'.

Objectief geldig bewijs gaat Slootweg dus niet leveren in de door hem aangespannen rechtszaak. Hij wil de waarheid van zijn standpunt aantonen op grond van wat hij noemt een betrokken en persoonlijke inspiratie, die in subjectieve zin weerklank oproept. Op deze wijze wil hij een rechtsfilosofie naar voren brengen die de verhouding van recht, existentie en esthetica verheldert, inzicht geeft in de dubbelzinnigheid en de tragedie van het recht, om op grond daarvan de contouren te schetsen van een toekomstige maar oorspronkelijke, meer menselijke, rechtsfilosofie. Kenmerkend voor deze 'ware rechtsfilosofie' is dat de liefdevolle en gewetensvolle verantwoordelijkheid tegenover de ander centraal staat, vanuit het persoonlijk geweten van de existerende persoonlijkheid. Want alleen in de waarheid van de ontmoeting toont God zich in het gelaat van de ander. Ook heeft deze ware filosofie oog en aandacht voor het recht achter het recht, dat is het recht van de unieke individuele persoon, die nooit gevangen kan worden in de begrippen van het recht. 
Slootweg beroept zich voor de uitwerking van zijn betoog op filosofen als Kierkegaard, Nietzsche, Berdjajev, Shestov, Heidegger, Levinas en Derrida. De protestantse rechtsgeleerde Paul Scholten wordt opgevoerd als de verbindende schakel tussen enerzijds het recht, anderzijds religie en esthetica. Slootweg verwijst daarbij met name naar de 'christelijk-existentiële antropologie' van Scholten, en naar diens stelling dat het recht niet een doctrine of techniek is, maar een kunstwerk. Naar aanleiding van Scholtens denkbeelden over rechtsbeslissing en geweten betoogt Slootweg dat de zorg van Scholten was dat de persoon altijd de institutie van het recht moet blijven bezielen. In het voetspoor van Scholten beroept Slootweg zich ook op de Zwitserse theoloog Emil Brunner, de joodse filosoof-theoloog Martin Buber, de filosoof Karl Jaspers en de Nederlandse filosoof-pedagoog Philip Kohnstamm. De hiervoor genoemde denkers vormen een heterogeen gezelschap, en dat verklaart wellicht waarom Slootweg afwisselend van 'christelijke existentialisme', 'existentialistisch personalisme', soms ook van 'protestants personalisme' en van 'postmodernisme' spreekt. Slootwegs terminologie wordt met name bepaald door de denker die hij bespreekt. Met de vraag of bijvoorbeeld de gelovige Kierkegaard op enig punt anders dacht dan de 'God is dood'-filosoof Nietzsche, laat Slootweg zich niet in. Hij schakelt beiden in voor zijn eigen pleidooi.

Slootweg verbindt aan zijn beschouwingen ook suggesties voor de rechtspraktijk. Niet alleen de wetgever en de rechter, maar ook de advocaat heeft volgens hem een rechtsvormende taak. Door zijn 'productieve en creatieve interpretaties' kan hij wettelijke beginselen omvormen, zodat die beter aansluiten bij de maatschappelijke werkelijkheid die ze moeten vertegenwoordigen. En door zijn 'creatieve verbeeldingskracht' kan hij partijen ertoe brengen de werkelijkheid anders te zien en zich te verplaatsen in de ander. De advocaat dient niet alleen het belang van zijn cliënt, maar ook het doel van het recht: de ontwikkeling van de persoon, en de vorming van een gemeenschap van naasten. Daarom moeten wetgeving en rechtsvorming ook begrepen worden langs de lijn van de dialoog: als een vorm van interactie tussen overheid, rechter en burger. De kwaliteit van deze communicatie zou moeten worden afgemeten aan het 'existentiële gehalte' daarvan, wat het tegenovergestelde is van een 'dogmatische monoloog'.

Slootweg heeft een punt als hij wijst op het gevaar dat het recht onpersoonlijk wordt. Recht, rechtswetenschap en rechtsfilosofie moeten vanuit een persoonlijke overtuiging en inspiratie beoefend worden, willen ze werkelijk van dienst kunnen zijn voor het menselijk (samen)leven. En daarbij spelen religie en levensbeschouwing een rol die door een rationalistische benadering van het recht inderdaad ten onrechte onderschat en veronachtzaamd wordt.

Toch overtuigt Slootwegs pleidooi niet. In de eerste plaats doet hij geen recht aan de denkers op wie hij zich beroept. Zo maakt hij bijvoorbeeld niet duidelijk op welke manier hij de denkbeelden van de christelijke denker Kierkegaard en de filosoof van de antichrist Nietzsche met elkaar verbindt. Vanuit Slootwegs subjectieve positie is dat mogelijk geen probleem, maar het geeft zijn uiteenzetting een gebrek aan rationele helderheid die afbreuk doet aan de overtuigingskracht daarvan. 
In de tweede plaats, en dat hangt met het voorgaande samen, is niet duidelijk hoe de theologische en filosofische elementen in zijn betoog met elkaar verbonden worden. Slootweg wil een postmoderne 'religieloze religie' voorstellen. Het verhaal van de zondeval uit Genesis gaat voor hem niet over het historisch begin van de mensheid, maar reflecteert de oorspronkelijke onkenbaarheid van het begin. Desalniettemin baseert Slootweg op diezelfde zondeval de stelling dat rationalisme en wetenschap 'intrinsiek zondig' zijn omdat zij een bedreiging voor het leven vormen. Echter, 'zonde' is een theologisch begrip dat betrekking heeft op de verhouding tussen mens en God. Men kan het zondebegrip in de filosofie niet introduceren, zonder dat dit begrip van betekenis verandert. Slootweg laat echter na duidelijk te maken wat hij in filosofische zin met 'zonde' bedoelt, waardoor de lezer in het duister tast over de bedoeling daarvan. Uiteraard suggereert de uitdrukking 'religieloze religie' al een paradox. Maar ook een paradox kan in elk geval worden gepresenteerd en toegelicht. Dat laat Slootweg na. 


\section{SUMMARIES}

\section{Belgium and Democratic Constitution- Making: Prospects for the Future?}

Ronald Van Crombrugge

How constitutions are changed - and more importantly: how they should be changed is the subject of ongoing debate. There seems to be a growing consensus, however, that in order for a constitution to be considered legitimate it is required that it was created through a democratic process. This growing consensus stands in sharp contrast with the Belgian experience of constitutional change as an essentially elite-led process that takes place behind closed doors. This article seeks to explore the possibilities for more democratic forms of constitutional change in Belgium. It does so by evaluating and comparing two examples of democratic constitution-making, namely the constitution-making processes In South Africa (1996) and Iceland (2012). On the basis of these two examples, several concrete suggestions will be made, which are not only relevant for the Belgian case but can be applied more broadly to other countries as well.

\section{The Demos as a Plural Subject}

\section{Bas Leijssenaar}

Existing conceptualizations of the demos fail to treat issues of composition and performativity consistently. Recent literature suggests that both aspects are required in a satisfactory account of the demos. An analysis of this literature suggests several desiderata that such an account must meet. I approach the definition of demos with a conceptual framework derived from Margaret Gilbert's plural subject theory of social groups. I propose an account of demos as a plural subject, constituted by joint commitment. This account offers an improved and consistent understanding of normativity, composition, agency, and cohesion of demos.

\section{De nominalistische theorie van de rechtssubjecten}

Robert Jan Witpaard

In dit artikel presenteer ik een nieuwe 'nominalistische' theorie van de rechtssubjecten en laat ik zien waarom geen van de tot nu gepresenteerde theorieën de toets der kritiek kan doorstaan. Het artikel valt uiteen in een constructief en een kritisch deel. In het constructieve deel presenteer ik eerst de nominalistische theorie van de rechtssubjecten. Deze theorie richt zich op de persoonlijke elementen van het rechtssysteem en begrijpt rechtspersonen en organen als namen die uitsluitend bestaan binnen het rechtssysteem. In het kritische deel presenteer ik vervolgens een overzicht van de tot nu toe verdedigde theorieën van de rechtspersoon. Het gaat daarbij respectievelijk om de sociaal-biologische of organische leer, de sociologische leer, de sociologisch-juridische leer, de fictieleer en de leer van het (gepersonifieerde) normencomplex. Aan de hand van enkele algemeen geaccepteerde kenmerken van de rechtspersoon laat ik ten slotte zien waarom geen van deze alternatieve theorieën de toets der kritiek kan doorstaan. 


\section{AUTHOR INFORMATION}

Dr. Marieke Borren werkte tot voor kort als postdoctoraal onderzoeker aan de faculteit filosofie van de Universiteit van Pretoria, Zuid-Afrika. Op dit moment is ze UD filosofie aan de Open Universiteit en UD gender en postcolonial studies aan de Universiteit Utrecht.

Mr. drs. Harry Groenenboom studeerde Nederlands recht en filosofie aan de Erasmus Universiteit Rotterdam (EUR). Hij werkt als advocaat bij Janssens Den Boef Advocaten in Houten.

Bas Leijssenaar is $\mathrm{PhD}$-candidate at the Institute of Philosophy, Centre for Social and Political Philosophy of the University of Leuven.

Dr. François Levrau studeerde klinische psychologie en moraalfilosofie en promoveerde in de sociale wetenschappen aan de Universiteit van Antwerpen.

Dr. Antoinette J. Muntjewerff (Ph.D., MSc., LL.M.) is UD juridische methodologie aan de Universiteit van Amsterdam.

Prof. mr. Wouter Veraart is hoogleraar Encyclopedie van de Rechtstwetenschap en Rechtsfilosofie aan de Vrije Universiteit Amsterdam en hoofdredacteur van Netherlands Journal of Legal Philosophy.

Mr. dr. Robert Jan Witpaard is jurist bij de Afdeling Verdragen van het ministerie van Buitenlandse Zaken. 


\section{Boomjuridisch opleidingen}

webinars

video's

Pevents

\section{Nieuw: Masterreeks KEI alle ins en outs rondom het procesrecht}

Webinar 1: Het digitale dossier

mr. Menno Weij | 2 oktober 2017

Webinar 2: Basis en maatwerk: de processtukken

mr. Matthijs Ariëns | 2 november 2017

Webinar 3: Basis en maatwerk: de zittingen en de regiefunctie van de rechter

mr. Hans Steenberghe | 15 november 2017

Webinar 4: Incidenten, uitspraken, verzet en hoger beroep, overgangsrecht

mr. Steven Venhuizen | 30 november 2017

Ga naar www.boomjuridischopleidingen.nl voor meer informatie of gelijk inschrijven 


\section{Introduction}

Wouter Veraart, Bridging the Gap

\section{Opinion}

Marieke Borren, Human Rights Activism and the Politics

of Smell and Noise

\section{Articles}

Ronald Van Crombrugge, Belgium and Democratic Constitution-Making: Prospects for the Future?

Bas Leijssenaar, The Demos as a Plural Subject

Robert Jan Witpaard, De nominalistische theorie van de rechtssubjecten

\section{Book reviews}

Antoinette Muntjewerff, Goos Cardol, Trudy Veerman,

Annemieke Wolthuis (red.), Jongensbesnijdenis bezien vanuit mensenrechtelijk perspectief

François Levrau, Jonathan Wolff, An Introduction to Political Philosophy. Third Edition

Harry Groenenboom, Timo Slootweg, Uit de schaduw van de wet 110 